\title{
Analysis of $B$ cell subsets in severe cutaneous adverse reaction
}

\author{
Hiroaki Azukizawa ${ }^{*}$, Kenichi Kato ${ }^{2}$, Ichiro Katayama ${ }^{2}$ \\ From 6th Drug Hypersensitivity Meeting (DHM 6) \\ Bern, Switzerland. 9-12 April 2014
}

\section{Background}

$\mathrm{T}$ cells play an important role in the pathogenesis of severe cutaneous adverse reaction (SCAR), while the role of B cell immunity in SCAR is unclear. It has been reported that number of $B$ cell and serum IgG are decreased in the patient's peripheral blood of drug-induced hypersensitivity syndrome (DIHS) / drug reaction with eosinophilia and systemic symptoms (DRESS) in the acute stage. Regulatory $\mathrm{B}$ cell (Breg) is a IL-10 producing cell and negatively regulates cellular immunity in the mouse autoimmune disease model. Also in the mouse model, B-1 B cell secretes immunoglobulin against microbial infection in a $\mathrm{T}$ cellindependent manner. Recently, Breg and B-1 B cell were identified as minor populations of human $B$ cells in the peripheral blood, however, the roles of these $\mathrm{B}$ cells in SCAR are unknown. Here, we studied the ratio of Breg and B-1 B cells in the peripheral blood B cells of SCAR patients.

among patients of TEN and DIHS and there was no clear tendency.

\section{Conclusion}

Although the pathological roles of Breg and B-1 B cell in SCAR are still unclear, they might contribute to drugspecific $\mathrm{T}$ cell activation or herpes virus reactivation.

\section{Authors' details}

'Department of Dermatology, Course of Integrated Medicine, Osaka University, Japan. ${ }^{2}$ Osaka University, Department of Dermatology, Japan.

Published: 18 July 2014

\section{doi:10.1186/2045-7022-4-S3-P44}

Cite this article as: Azukizawa et al:: Analysis of B cell subsets in severe cutaneous adverse reaction. Clinical and Translational Allergy 2014 4(Suppl 3):P44.

\section{Method}

Three patients of toxic epidermal necrolysis (TEN), DIHS/ DRESS, and three healthy controls were involved in this study. Peripheral blood mononuclear cells of SCAR patients in both acute stage and recovery stage were stained. CD24hi, CD27+, CD19+ cells and CD27+, CD43 + , CD20+ cells were analyzed as Breg and B-1 B cells, respectively.

\section{Results}

The ratio of B cells in the peripheral blood was decreased in the acute stage SCAR. Furthermore, the ratio of Breg in the CD19+ cells was decreased in the acute stage of DIHS. On the other hand, the ratio of B-1 B cells was different

${ }^{1}$ Department of Dermatology, Course of Integrated Medicine, Osaka University, Japan

Full list of author information is available at the end of the article

Submit your next manuscript to BioMed Central and take full advantage of:

- Convenient online submission

- Thorough peer review

- No space constraints or color figure charges

- Immediate publication on acceptance

- Inclusion in PubMed, CAS, Scopus and Google Scholar

- Research which is freely available for redistribution

Submit your manuscript at www.biomedcentral.com/submit
() Biomed Central 